\title{
ESBAN
}

\author{
af Eva Gulløv
}

\section{Følelseshåndtering i et socialhistorisk perspektiv}

Jeg befinder mig på et rådgivningscenter for familier i krise. Her gives psykologhjælp til par, der er ved at gå fra hinanden, og der afholdes samtaler forældre i samarbejde og konfliktløsning og gruppemødeterne er kurser for serverer et forløb, hvor en gruppe 7-10 årige bøuppemøder for børn. Jeg obunder professionel vejledning at udveksle erfaringer om, hver anden uge for at være $\mathrm{i}$ en familie, hvor forældrene skal skilles eller, hvordan de oplever Denne tirsdag beder den professionelle, Thomas, hvert gået fra hinanden. cirkel på et stykke papir. Han siger: "Vælg en følelse, sorn om at tegne en mærker. Måske mærker du den tit, måske sjældent. Pom du nogle gange hvor meget følelsen fylder i dig". Der er en del spørgsmal te tegne i cirklen, min forbløffelse går spørgsmålene på, om man "r. om man "må bruge flere farver", om man "skal gøre sig umage", om man af en følelse og gengive den som strak fordring om at identificere omfanget ikke anledning til tvivl. Da de er førrelsesforhold i en cirkel giver åbenbart tegning i en firkant. "Prøv at sætte et billede skal de omsætte deres følelse til en ud? Hvad vil du kalde følelsen?" og beder dem derpå svare skriftligt pas giver dem tre minutter til at tegne følelsen på besøg? 2) Hvad skete der på spørgsmålene: 1) Hvornår kommer dig til at gøre? Øvelsen bliver fulgt sidst, den var på besøg? 3) Hvad får den fingere dialog, hvor hvert barn forden befinder sig, og hvad de gør ved den. 
Da han kommer til Tasha siger han: "Tasha, kan du huske sidste gang, der lavede vi denne her øvelse med dig alene. Du sagde, at du var vred, og da jeg bad dig om at tegne det, tegnede du sådan en cirkel med pigge på. Har du tænkt på et navn til den?"

Tasha: "Ja, jeg kalder den en "pig-planet". Jeg tænker på den hver gang, jeg er vred".

Thomas: "Er det vrede, der er den følelse, du har tænkt på i dag?"

Tasha: "Nej i dag er det tristhed. Jeg føler mig rigtig trist i maven. Jeg ved ikke, hvorfor den kom".

...

Lidt efter vender Thomas sig mod Emilie: "Hvilken følelse kommer på besøg hos dig?"

Emilie (med stille stemme, der næsten er i falset): "Sorg. Det fylder hele cirklen".

Thomas: "Ja, du har fyldt hele cirklen ud. Hvordan har du tegnet følelsen?"

Emilie viser, at hun har tegnet den som en "klump, der græder" (tegningen viser et ansigt med tårer, der løber langt længere, end ansigtet er). Thomas spørger til de mange tårer, og hun forklarer, at "den er meget ked af det og græder hele tiden". Thomas spørger, om hun også græder.

Emilie: "Nej, det er klumpen, der græder. Jeg græder ikke".

Thomas: "Hvornår græder klumpen?"

Emilie: "Den græder, når jeg tænker på, at mine forældre er skilt".

Thomas: "Hvor sidder klumpen?"

Emilie: "Nederst i halsen".

...

Efter sessionen fortæller Thomas mig, at han gennem sådanne "eksternaliseringsøvelser" forsøger at få børnene til at udvikle et sprog om deres følelser. Det kan hjælpe dem til at genkende og kommunikere deres følelser, så de kan dele dem og se, at andre kan føle, som de selv. Det kan forebygge social isolation og mere destruktive former for kommunikation.

Jeg vil bruge denne situation som afsæt for nogle refleksioner over den aktuelle opmærksomhed på følelsesudtryk og følelseshåndtering i pædagogiske sammenhænge. Uge efter uge forlader jeg observationerne fascineret af, hvordan børnene formår at fortælle nuanceret om deres følelsesmæssige tilstand og erfaringer. Jeg er også forbløffet over den pædagogiske tilgang og forundret over det forhold, at sådanne tilbud gives til børn i mange af landets kommuner. Denne forundring forstærkes af, at det langt fra er den eneste type arrangement, der fokuserer på følelsesudtryk og følelseshåndtering. En lang række rådgivningsforløb, terapeutiske modeller og adfærdsregulerende programmer er gennem de sidste 10-15 år blevet del af de offentlige tilbud til børn og forældre. F.eks. er det blevet udbredt at tilbyde kurser til nye forældre, hvor der fokuseres på forhandling, konflikthåndtering og selvkontrol, 
ang, der 'g da jeg Har du er gang,

Jeg ved

Jå besøg

der hele

tet følel-

(tegninr). Thoed af det

ernalisefølelser. å de kan ial isola-

sver den pædagoascineret mæssige lgang og $\mathrm{f}$ landets $n$ eneste sring. En ulerende tilbud til ye forælvkontrol, og i daginstitutioner, skoler og familierådgivning er det i dag almindeligt at arbejde med specifikke koncepter og redskaber til håndtering og kontrol af følelsesudtryk.

Men hvorfor dette udbredte fokus? Og hvorfor er det blevet en opgave for offentlige institutioner at udbyde programmer, der kan lære børn, unge og forældre at verbalisere og kontrollere deres følelser? Inspireret af sociologerne Norbert Elias og Cas Wouters vil jeg i dette essay argumentere for, at denne opmærksomhed skal forstås i sin socialhistoriske sammenhæng. Den kan ses som udtryk for sociale dynamikker, der over tid har gjort følelsesudtryk til en stadig mere vigtig, men også potentiel destabiliserende dimension ved social omgang og respektabilitet. Og da pædagogiske indsatser reflekterer sociale dynamikker, er det blevet en pædagogisk opgave at inddæmme de følelsesmæssige kræfter ved at lære børn at udtrykke sig i en særlig kulturelt accepteret form.

\section{Programmer for følelseshåndtering}

Opmærksomhed på, hvordan børn udtrykker og håndterer deres følelser, er ikke ny. Men den har i nyere tid fået en særlig betoning og bevågenhed både i kommunalforvaltninger og institutioner, der arbejder med børn og unge. I mange af landets kommuner har man således introduceret målrettede programmer for følelses- og adfærdsregulering, der i første omgang er rettede mod forældre og udsatte børn, men programmerne er gradvist blevet overført og tilpasset daginstitutioner og skoler (se Socialstyrelsen, om dokumenterede metoder). ${ }^{1}$ Nogle af programmerne er udviklet i andre lande (især USA, Norge, Sverige), andre tiltag er udviklet herhjemme, men i begge tilfælde sigter de mod at give de voksne (professionelle og forældre) redskaber til at understøtte en positiv kommunikation og håndtere egne reaktioner (især vrede, irritation, frustration, afmagt) og samtidig sikre en systematisk måde at arbejde med børns følelsesudtryk og beherskelse af især sorg, vrede og aggression. På tværs af initiativer og programmer finder man en relativ konsistent argumentation om, at en række sociale problemer (marginalisering, dårlige skoleresultater, mobning, opgivelse af skolegang, men også længerevarende konsekvenser som arbejdsløshed, depression, misbrug og udstødelse) har deres årsag i manglende sociale færdigheder (se f.eks. programbeskrivelser hos Elias et al. 1997; Gregersen 2002; Casel 2003, Kimber 2004; Webster-Stratton 2006; Elias \& Zins 2007). Det gælder derfor om tidligst muligt at lære børn hensigtsmæssige måder at udtrykke sig på og ikke mindst identificere de børn, der af forskellige grunde afviger i deres adfærd fra det normale, så man kan lave mere målrettede indsatser. At dømme efter programmaterialerne er det hensigten at forebygge, så børn og unge kan navigere uden om de risici, der på sigt kan føre til, at de ikke får uddannelse og arbejde. Nogle af de forhold, der især fremhæves som positive i forvaltninger, er, at programmerne er systematiske, effektive og støtter de professionelle i deres prioriteringer (SocialFo- 
kus 2012; diskussion hos Buus et al. 2012). Den underliggende præmis synes at være, at når børnene får redskaber til at udtrykke sig på hensigtsmæssige måder, har de et bedre udgangspunkt for at danne positive sociale relationer og omgangsformer, hvad der igen vil øge deres muligheder for at få en mere positiv social udvikling på lang sigt.

Det nye i denne tilgang er som nævnt ikke selve ideen om, at der skal arbejdes med børns følelsesudtryk og sociale optræden (se f.eks. Norbert Elias omfattende værk 1994 opr. 1939; 1998), eller at det er en opgave for samfundets børneinstitutioner. Adfærdsregulering har altid været en del af opdragelsesprojektet i skoler og småbørnsinstitutioner om end med andre midler og mål. Men den systematiske indsats i forhold til følelsesregulering og verbalisering af følelser er ny, ligesom det er af nyere dato, at det hviler på en opfattelse af, at der er direkte sammenhæng mellem børns følelsesudtryk, deres sociale omgang, deres udvikling og livsmuligheder og i videre perspektiv samfundets sociale stabilitet. Der opstilles i flere af de ovenfor refererede manualer en direkte og kausal relation mellem den enkeltes sociale og emotionelle kompetencer og sociale problemer på samfundsniveau.

I deres analyser af, hvordan sådanne følelsesprogrammer indgår i det pædagogiske arbejde i svenske skoler, viser de pædagogiske forskere Åsa Bartholdsson (2007) og Magnus Dahlstedt m.fl. (2011), hvordan professionelle konkret arbejder med at lære eleverne at reflektere over deres egne bevæggrunde, opførsel og udtryksformer. Med en foucaultsk inspiration peger begge studier på, at følelsesarbejdet indgår som en vigtig pædagogisk komponent, der både fungerer som en subtil form for social kontrol og et moralsk imperativ for den anerkendelsesværdige borger. Individet er både problemet og løsningen ikke bare på de konkrete læringsudfordringer i skolen, men også på problemer, som samfundet står overfor, hvorfor indsatsen retter sig mod individets tilpasning (Bartholdsson 2007; Dahlstedt et al. 2011:410). Denne fortolkning ligger i tråd med det sociologen Frank Furedi betegner som en "terapeutisk kultur" (Furedi 2004), hvor den enkelte i stigende grad opmuntres til at arbejde med sig selv, dvs. erkende styrker og svagheder og være i stand til at kontrollere sine følelsesudtryk ikke bare for sin egen skyld, men for at det større fællesskab kan fungere. Fra det perspektiv er den udbredte opmærksomhed på følelsesregulering i børneinstitutioner et udtryk for en ny form for normaliseringslogik, hvor bestemte måder at tænke og handle på fremstår som normalt med eksplicit distance til det, der fremstår uhensigtsmæssigt og unormalt (Dahlstedt et al. 2011:412). Et centralt mål bliver at lære den enkelte at vurdere sin egen opførsel og udtryksform og tage ansvar i et forpligtet forhold til fællesskabet og i videre forstand samfundet. Individet kommer dermed i centrum for en bestræbelse mod at sikre samfundets stabilitet. 
əmis synes tsmæssige relationer få en mere er skal arrbert Elias ir samfunaf opdraIre midler ng og verriler på en dtryk, deserspektiv erede ma'g emotior i det pæÅsa Bartessionelle 1e bevægseger begk kompo$t$ moralsk oroblemet slen, men retter sig 110). Dener som en d opmunog være i syld, men udbredte for en ny tandle på hensigtser at lære nsvar i et Individet idets sta-

\section{Følelsesudtryk i et civilisationsteoretisk perspektiv}

Der er ingen tvivl om, at man kan se den udtalte opmærksomhed på følelsesudtryk og det intensiverede pædagogiske arbejde med selvkontrol som et normaliseringsprojekt. I det lys er der tale om en interventionsform, der skal lære børn og unge at beherske og kontrollere sig selv for at kunne indgå i sociale interaktioner på mere hensigtsmæssige måder både nu og her og på lang sigt, og både for deres egen og for samfundets skyld. Imidlertid savner man en forklaring på, hvorfor denne interesse er opstået. Med inspiration fra figurationssociologien vil jeg her pege på, at den udtalte opmærksomhed på at lære børn at erkende, genkende og udtrykke deres følelser på anerkendte måder må ses i lyset af en længere socialhistorisk proces. Med det perspektiv kan man nemlig se, hvordan bestemte kontrollerede former for følelsesudtryk er blevet en væsentlig dimension i den sociale dynamik, dvs. indgår i menneskers vurderinger af hinanden og spiller en rolle for, hvordan status og distinktion er distribueret socialt.

I Norbert Elias store værk, om det han betegner som "civiliseringsprocessen", analyserer han en langvarig historisk udvikling mod stadigt mere integrerede statssamfund. Med udgangspunkt i Tyskland og Frankrig argumenterer han for en sammenhæng mellem samfundsorganisation (især statens rolle), sociale omgangsformer og individets følelsesstruktur (Elias 1994 opr. 1939). I takt med øget befolkningstæthed og funktionsdeling opstår en høj grad af afhængighed mellem samfundets medlemmer, eller det Elias betegner som "interdependenskæder", der op gennem århundrederne bliver stadig længere og mere differentierede (ibid. 370). Kombinationen af statsmonopolisering af vold og øget social integration skaber, argumenterer han, større fysisk sikkerhed for samfundets medlemmer, men fordrer også, at de må optræde forudsigeligt dvs. udvise selvkontrol og tilpasse deres adfærd til andre menneskers forventninger (ibid. 366-369, 429). I en samfundsorganisation baseret på medlemmernes indbyrdes afhængighed bliver forudsigelighed $\mathrm{i}$ omgang af afgørende betydning for ens sociale anseelse (se nøjere diskussion i Gilliam og Gulløv 2012, kap. 1). Elias argumenterer for, at normer for interaktion, udtryksformer og selvbeherskelse over tid indarbejdes i den enkelte som en habituel disposition; en stadig opmærksomhed på andre menneskers vurderinger knyttet til følelser af skam ved overtrædelser. Frygten for andre menneskers volds- og magtudøvelse erstattes efterhånden af en social bevågenhed; en angst for at falde socialt igennem og en stræben efter social accept (Engebrigtsen 2006:112). Kort opsummeret viser Elias således, hvordan opførsel i det civile liv gradvist bliver en kilde til vurdering af både éns egen og andres status og grad af respektabilitet (Gilliam og Gulløv 2012:19).

Inspireret af denne tilgang peger Cas Wouters på, hvordan de sociale logikker fik en mere uformel, men ikke mindre socialt betydningsfuld karakter op gennem det 20. århundrede (Wouters 1986, 2004, 2011). Med afsæt i Nederlandene viser han, hvordan nye former for handel og produktion langsomt 
udfordrede gamle monopoler og nødvendiggjorde samarbejdsrelationer på tværs af sociale skel. Samtidig gav nye typer af transport og kommunikation anledning til andre og udvidede former for kontakt. Denne øgede integration mellem sociale lag medførte, at det blev problematisk at fastholde markeringer af stand og social distance (Wouters 2004:206). Det blev i stigende grad nødvendigt at kunne kontrollere og tilpasse sine følelsesudtryk til vekslende situationer.

Der var naturligvis mange flere årsager end de her nævnte til udjævningen af klasseskel op gennem det 20. århundrede (industrialisering, politisk mobilisering, urbanisering, demokratisering, arbejdsregulering osv.). Mit ærinde her er ikke at give en egentlig historisk redegørelse, men at pege på hvordan de etablerede normer for behørig social omgang og standsmarkering gradvist blev slækket som følge af ændrede hierarkier og grupperinger ("figurationer" i Elias terminologi). Det har imidlertid ikke betydet, at fordringerne til selvkontrol og følelsesudtryk er blevet mindre socialt betydningsfulde. Omgangsformer er en uadskillelig del af den sociale organisation, men der er sket ændringer $\mathrm{i}$, hvordan man skal interagere og udtrykke sine følelser, hvis man ikke vil falde igennem eller miste anseelse. Fra en forventning om at opføre og udtrykke sig i overensstemmelse med nogle relativt klare normer knyttet til ens placering $i$ et standshierarki, er det $\mathrm{i}$ højere grad ens personlige meritter, der skal sikre den sociale anseelse. Når hverken koder eller hierarkier er entydige eller fastlagte, bliver den enkeltes evne til fleksibel tilpasning og situationsafkodning en forudsætning for social anerkendelse og respektabilitet. Her gælder det med Bourdieus udtryk om at have "feel for the game" (1990: $64)$, dvs. en stadig opmærksomhed på ens egne udtryk i forhold til den sammenhæng, man er i. Og i den sociale dynamik bliver følelsesudtryk særlig væsentlige.

\section{Informalisering af omgangsformer}

Denne pointe kommer frem i Wouters historiske analyser af udviklingen i Nederlandene, hvor han viser, hvordan stort set alle sociale relationer gradvist blev mere uformelle og mindre hierarkiske i løbet af 1960erne og 1970erne, en periode hvor store grupper oplevede social opstigning (2004). Denne proces, som er helt genkendelig i en dansk sammenhæng, relaterede i både Danmark og Nederlandene til konsolideringen og ekspansionen af velfærdsstaten, som omfattede og integrerede stadig flere af samfundets grupper i sociale institutioner, der intenderet arbejdede for at overkomme forskelle og ændre interaktionsmønstre (ibid:209). Middelklassen blev udvidet og i takt hermed mistede tidligere tiders sociale koder for regulering af opførsel gradvist relevans og blev erstattet af mere uformelle og kontekstsensitive interaktionsformer. Med en fascinerende kulturel inversion blev opførsel, der tidligere blev set ned på og associeret med lavere social status som f.eks. at bande, gå afslappet klædt, være sammen med det andet køn eller bruge "du" i tiltale, gradvist udtryk 


\begin{abstract}
oner på
nikation

egration

arkerin-

de grad

:kslende

vningen

ik mobi-

:rinde

ivordan

gradvist

guratio-

zerne til

de. Om-

rer sket

vis man

t opføre

- knyttet

e merit-

ırkier er

ig og si-

tabilitet.

:" (1990:

en sam-

< særlig
\end{abstract}

en i Ne-

jradvist

erne, en

proces,

anmark

en, som

institu-

interak-

mistede

vans og

er. Med

: ned på

't klædt,

udtryk

for en statusgivende ligefremhed. Denne "informalisering", som er Wouters begreb for processen, bliver gradvist en social fordring (1977). Jævnbyrdighed og evne til at omgås forskellige mennesker uden konflikt bliver en forudsætning for anerkendelse og social integration. Eller som Wouters udtrykker det: "Social success did become more strongly dependent on a reflexive and flexible self-regulation, the ability to combine firmness and flexibilily, directness and tactfulness" (2004:210).

Selvom en sådan dyrkelse af uformelle omgangsformer umiddelbart fremstår som en slækkelse af sociale konventioner, argumenterer Elias for, at netop det tilsyneladende afslappede i sig selv fordrer en øget opmærksomhed på selvregulering (Elias 1994 opr. 1939). Med en ofte gentagen sentens karakteriserer han udviklingen som en "highly controlled decontrolling of emotional controls" (Elias i Wouters 2007:231). Netop når de sociale hierarkier og distinktioner ikke er givet, bliver det særlig vigtigt at kunne afkode andre menneskers følelsesmæssige stemninger og kunne beherske sine egne udtryk. At miste besindelsen og udvise tegn på fysisk dominans bliver i denne sociale formation stigmatiserende. Wouters argumenterer for, at ukontrollerede følelsesudbrud på den ene side er blevet mere tabubelagte, især når de opfattes som forsøg på dominans; på den anden side kan man samtidig iagttage bredere social accept af følelsesmæssige tilstande f.eks. udtrykt i virtuelle fantasier. Han argumenterer således for, at den øgede selv-kontrol er en grundlæggende forudsætning for, at folk kan eksperimentere med deres impulser og følelser mere ærligt, forudsat at denne eksperimentering sker med respekt for andre menneskers følelser (ibid:237). "The now dominant mode of emotion management has apparently reached a strength and scope that enables people to admit violent and/ or sexual emotions and impulses to themselves and each other, without provoking the fear of losing control and of having to give in to them" (ibid:238).

\section{Den anti-autoritære børneopdragelse}

Store sociale transformationer forårsager ændringer i omgangsformer og -normer og dermed også i opdragelsesprioriteringer. I dansk sammenhæng har de store sociale forskydninger gennem især sidste halvdel af forrige århundrede betydet markante ændringer både i de interaktionelle former og i de opdragende institutioners opgaver. Med opkomsten, udvidelsen og konsolideringen af middelklassen som den dominerende gruppe i den sociale figuration er det en social forudsætning for anerkendelse, anseelse og muligheder, at den enkelte kan begå sig i vekslende sociale sammenhænge uden at markere distance, overlegenhed eller underlegenhed. Det tilpasningsdygtige menneske er blevet et ideal i samfundet og dermed også en væsentlig opgave for samfundets børneinstitutioner.

Denne opgave rummer imidlertid nogle særlige udfordringer. I takt med informaliseringen af den sociale omgang er også autoritetsmarkering blevet 
tabuiseret. Det gælder også mellem generationer. Generationsrelationerne er generelt demokratiseret og emotionaliseret (Gilliam og Gulløv 2012: kap.2; Elias 1998). I stedet for normative anvisninger af, hvad der er rigtig og forkert optræden, retter det opdragende arbejde sig i højere grad mod at vejlede børn $\mathrm{i}$ at tage bestik af implicitte fordringer og umarkerede distinktioner og derudfra vurdere, hvad der er passende i konkrete situationer. Denne form for vejledning forudsætter samtale, dvs. den er baseret på verbalisering og fortolkning af oplevelser, erfaringer og følelser. I stadig øget grad er det blevet vigtigt - og opleves som rigtigt - for forældre at investere tid og energi i deres børns følelsesliv og engagere sig $i$ at guide børn $i$, hvordan de kan fortolke og vurdere både deres egne og andres udtryk (Bach 2015). Selvom relationerne er anderledes i de pædagogiske institutioner lægges der også her vægt på en anti-autoritær interaktion og guidning med prioritering af verbalisering af indtryk, overvejelser og begrundelser.

Den anti-autoritære norm betyder, at forældre såvel som pædagoger og lærere står over for den udfordring at skulle lære børn at kontrollere sig selv uden selv at udtrykke for stærk autoritet. De skal støtte hvert enkelt barn i at udvikle en nuanceret fornemmelse for, hvordan man skal udtrykke sine følelser på måder, der på én gang er autentiske og viser respekt for andre menneskers følelser. De skal sikre at børn kan tage bestik af og kan afstemme deres følelsesudtryk til skiftende situationer og kommunikere med folk med forskellig baggrund, og samtidig må de ikke være så føjelige, så de ikke står ved sig selv. Eller som Thomas fra rådgivningscenteret udtrykker det: Børn skal lære "at kunne give udtryk for deres følelser", men "de skal også kunne gøre det på måder, som andre kan forholde sig til og som ikke overskrider deres grænser. Det er den udfordring, jeg står med". Denne udfordrende balancegang gælder således ikke bare børn, men også de voksne opdragere, der også selv både skal optræde autentisk og kunne kontrollere deres egne impulser og følelsesudtryk. De skal både kunne rumme børns følelser og handlinger og samtidig være sikre på, at børnene ved hvor og hvordan, det er passende at udtrykke sig, uden at der kan henvises til et etableret normkodeks. Såvel børn som opdragere skal vide, hvornår de skal beherske deres følelsesudtryk eller snarere, hvordan de skal være "de-controlled in a controlled way". De skal kende de implicitte men vigtige normer for at udtrykke jævnbyrdighed og social anerkendelse og samtidig udtrykke deres egne synspunkter, interesser og følelser på en troværdig og autentisk måde. Disse udfordrende balancer er så meget desto mere vigtige, fordi følelseshåndtering er en uomgængelig del af de sociale relationer i dag. Det gør en forskel ift. status, distinktion og respektabilitet, hvordan man evner at beherske sig, udtrykke sig på en måde der anerkender og tilgodeser de tilstedeværende og undgår markeringer af overlegenhed eller dominans, men også udtryk for underlegenhedsfølelser. Når børnene i det indledende eksempel anspores til at fortælle om deres følelser på en bestemt måde, indsættes deres formentlig sammensatte oplevelser og 
ionerne er 12: kap.2; tig og forat vejlede ktioner og enne form isering og - det blevet srgi i deres ortolke og lationerne ir vægt på llisering af

agoger og Ire sig selv lt barn i at : sine følelre mennenme deres s med for<e står ved Børn skal unne gøre ider deres le balancee, der også ə impulser dlinger og assende at Såvel børn dtryk eller $r^{\prime \prime}$. De skal ;hed og soteresser og ancer er så yelig del af og respekmåde der ;er af overlelser. Når -es følelser evelser og erfaringer med sorg og krise i et bestemt sprog, der på én gang er personligt og kan deles med andre. Gennem de gentagne sessioner i rådgivningscenteret er det netop det, der er hensigten: Børnene skal lære at udtrykke sig i en balanceret og legitim form, en slags følelsernes lingo, som på én gang er privat og offentlig, bekendende og socialt acceptabel, så andre kan forholde sig til, acceptere og håndtere deres følelser.

\section{En særlig emotionel udtryksform}

Pointen her er, at vi må forstå de aktuelle prioriteringer af følelsesudtryk i det pædagogiske felt $\mathrm{i}$ lyset af større historiske og sociale transformationer i samfundet. Staten og dens institutioner står ikke uden for (eller over) de sociale dynamikker, men skal forholde sig til de udfordringer, de rummer. Det gælder ikke mindst børneinstitutionerne - skoler og daginstitutioner, - hvis opgave det er at gøre børn i stand til at begå sig i det samfund, de vokser op i. Kigger man over de pædagogiske institutioners historie står det klart, at fortolkningen af denne opgave markant har ændret karakter. Fra at lægge vægt på lydighed, autoritetsrespekt og flid er betoningen i dag at lære børn aktivt og fleksibelt at indgå i samarbejde med mennesker med forskellig baggrund. Sociale distinktioner og ulighed i indflydelse er nedtonet og tabuiseret, men jo ikke forsvundet og ustabilitet kan latent springe frem fra sprækkerne i den harmoniske orden. Med denne udfordring bliver det vigtigt at lære børn selvbeherskelse og afbalancerede omgangsformer, ligesom det bliver centralt at sikre, at de kan håndtere og udtrykke deres følelser på en kulturelt og socialt acceptabel måde. Følelser kan udfordre den gnidningsfrie sameksistens og den tilsyneladende jævnbyrdighed. Ikke mindst kraftfulde følelser som sorg og vrede kan føre til aggression, social splittelse og destruktiv vold. Det opdragende arbejde er forebyggende; fokus er rettet mod at sikre, at følelser bliver tæmmet og udtrykt i en koreograferet og kontrolleret form, der ikke generer andre eller udfordrer den sociale stabilitet.

Sociologen Eva Illouz (2007) har vist, hvordan følelsesudtryk er forbundet med opkomsten og udviklingen af kapitalismen. Hun udfordrer skellet mellem det offentlige, det private og det intime og viser, hvordan en psykologisk og psykoterapeutisk terminologi langsomt er blevet en integreret del af såvel de private som de civile og professionelle sfærer i samfundet, hvad der gradvist har etableret en dominant emotionel udtryksform, som på én gang er personlig og performativ, bekendende og kontrolleret, verbal og derfor acceptabel. Hendes fokus på kapitalismen giver hendes analyser en anden vinkel end Elias' og Wouters', men også hun viser, hvordan følelser og følelsesudtryk må forstås i den sociale og kulturhistoriske sammenhæng, som de tager form i og sætter præg på. Og ligesom Elias understreger hun, at disse transformationer ikke bare har ændret ved formen, men over tid også har ændret ved den følelsesmæssige struktur og har tilføjet en særlig rationalisering af følelseslivet (ibid:30). Denne pointe er væsentlig i diskussionen af det 
følelsesarbejde, der aktuelt pågår i pædagogiske sammenhænge i Danmark. Følelser skal udtrykkes i en bestemt nærmest kodificeret form, der indebærer en særlig rationalisering. Det indledende eksempel er illustrativt i den henseende. De familiære forandringer antages at give børnene stærke følelsesmæssige reaktioner, som de skal finde et legitimt og afbalanceret sprog for. De skal lære at "eksternalisere deres følelser", som Thomas forklarer mig, men det skal ske på en kontrolleret måde. Øvelsen går ud på at oversætte de sammensatte, men negative følelser til et abstrakt og verbalt sprog, som andre kan forholde sig til, men også lære børnene en særlig form for refleksion over det følelsesmæssige udtryk. Det er et forebyggelsesarbejde rettet mod at inddæmme det potentielt destruktive til en acceptabel social form; et særlig objektiveret sprog, der i sig selv bliver håndterligt og paradoksalt nok i nogen grad disengageret fra konkrete sociale relationer.

Det fascinerende her er dels, hvordan de observerede børn på rådgivningscenteret faktisk accepterer og behersker denne koreograferede kulturelle udtryksform. Dels at denne emotionelle stil er blevet en integreret del af samfundets formelle socialiseringsproces. Der arbejdes gennemgående og systematisk på at lære børn at udtrykke deres følelser i en bestemt verbaliseret og ofte ret abstrakt form, der ikke vækker anstød eller skaber splittelse. Interessant nok rummer selve det stærke fokus på at lære børn en særlig form for følelsesartikulation således en formalisering af det informelle; en transformation af den enkeltes sammensatte og personlige erfaringer til en verbal form, man kan gøre til genstand for analyse og træning.

Det skal påpeges, at til trods for det udtalte sigte mod at sikre hensigtsmæssige sociale omgangsformer og stabilitet, rummer dette arbejde med bestemte former for følelsesudtryk i sig selv en distinktiv dimension. I skoler og daginstitutioner er der i dag en udtalt bevågenhed på børns følelsesmæssige udtryk, og de børn og unge, der udtrykker sig for voldsomt, for råt eller aggressivt omfattes af bekymring og særlige pædagogiske tiltag. Det særlige følelsessprog står således ikke uden for de sociale normer, vurderinger og distinktioner, det formaliserede sprog til trods. Tværtimod fungerer det i nogen grad som en målestok for, hvem der behersker, og hvem der ikke behersker de legitime koder for social omgang. I den forstand virker det opdragende arbejde ikke entydigt befordrende for den fleksible sociale omgang eller nødvendigvis socialt integrerende, men risikerer i stedet at etablere og legitimere sociale distinktioner i en samfundsorganisation præget af mangel på autoritative distinktionskoder og et etableret kulturelt ideal om social integration og jævnbyrdighed.

\section{Afrunding}

Der er flere bud på, hvorfor der i stigende grad lægges så stærkt vægt på følelsesudtryk i tilbud til børn og deres forældre gennem udbud af koncepter, programmer og rådgivning. Subtile styringsformer, new public management, 
Janmark. ıdebærer den henfølelsesprog for. arer mig, rsætte de som anefleksion at $\bmod$ at et særlig $\mathrm{k}$ i nogen

å rådgivde kultusret del af ide og syrbaliseret else. Inte, form for insformabal form,

hensigts2 med beskoler og smæssige t eller agat særlige ger og diet i nogen behersker dragende eller nødlegitimere a autoritajration og

ægt på føsoncepter, ragement, feminisering af pædagogikken, individualisering er nogle af de begreber, der i forskellige sammenhænge er blevet introduceret for at forklare fænomenet eller analysere årsager eller konsekvenser. Mit ærinde med dette essay har været at pege på de typer af sammenhænge, der placerer følelseshåndtering i en større socialhistorisk sammenhæng. Fra det perspektiv afspejler den stærke prioritering af at lære børn at håndtere deres følelser nogle større sociale bevægelser i samfundet, som over tid har påvirket de civile omgangsformer og dermed også det pædagogiske arbejde. I takt med at samfundsstratificeringer er jævnet mere ud, middelklassen blevet udvidet og den sociale integration forstærket, er ukontrollerede følelsesudtryk - især aggression - potentielt destabiliserende ikke bare for den enkelte, men også for den sociale sammenhæng og integration. De opdragende tiltags opgave er at være forebyggende i forhold til sociale problemer. De skal arbejde for social stabilitet blandt andet ved at sikre, at børn er i stand til at begå sig i vekslende sociale sammenhænge og kan balancere deres udtryk, så de hverken hævder sig, virker truende eller kuede. De enkelte børn skal helst kunne aflæse andre og kunne beherske og tilpasse deres sociale udtryk til vekslende situationer, men gøre det på måder, hvor de samtidig er i stand til at give udtryk for deres synspunkter og følelser. Det er disse sammensatte krav til afbalanceret følelsesinteraktion, som ligger bag den aktuelle prioritering af at arbejde med redskaber til følelseshåndtering i pædagogiske tilbud. Følelsesudtryk er en vigtig del af den sociale interaktion, men i en socialt sammensat sammenhæng også en potentielt udfordrende del. Den stærke prioritering af at lære børn - og deres forældre - at håndtere konflikter og følelser ved at omsætte dem til et abstrakt og kodificeret verbalt sprog kan således fortolkes som udtryk for inddæmning af potentielt destabiliserende kræfter - paradoksalt nok gennem formalisering af et kodeks for følelsesudtryk. Og denne inddæmning er blevet en opgave for samfundets opdragelsesinstitutioner, fordi den er en del af den værdisætning af det fleksible menneske, som har etableret sig som statusgivende gennem det sidste halve århundrede. Ved at arbejde med en kulturel legitim form kan komplicerede følelser som sorg og vrede, tristhed og aggression finde et mere standardiseret udtryk, der kan håndteres og justeres. Ja, helt konkret skraveres ind i en cirkel og indrammes af en firkant, som man derefter kan føre samtale om.

\section{Noter}

1. Det gælder f.eks. programmer som "Trin for Trin", "Jeg Kan", "De Utrolige År", "Positiv adfærd, støttende læringsmiljø og samvær (PALS)", Aggression Replace Training (ART), MultifunC, hvoraf flere er udviklet inden for det familieterapeutiske område, men i dag også bruges i daginstitutioner, skoler og specialtilbud for at lære alle børn hensigtsmæssige udtryksformer (se http://vidensportal.socialstyrelsen.dk/temaer/udadreagerende-adfaerd; http://socialstyrelsen.dk/ tvaergaende-omrader/dokumenterede-metoder-born-og-unge/om-dokumenterede-metoder). 


\section{Litteratur}

Bach, D. 2015: Overskudsfamilier. Om opdragelse, identitet og klasse blandt velstående familier $i$ Nordsjælland. Aarhus: Aarhus Universitets Forlag.

Bartholdsson, Å. 2007: Med facit $i$ hand. Normalitet, elevskap och vänlig maktutövning $i$ två svenska skolor. Ph.d. afhandling. Stockholm: Socialantropologiska institutionen, Stockholms Universitet.

Bourdieu, P. 1990: In Other Words: Essays Towards a Reflexive Sociology. Cambridge: Polity Press.

Buus, A.M., T.H. Grundahl, S.D.P. Hamilton, P. Rasmussen, U.N. Wiberg \& M. Wiberg 2012: "En kortlægning af arbejdet med evidensbaserede metoder i daginstitutioner i tre kommuner". Når evidens møder den pædagogiske hverdag. Rapport 2, Institut for Læring og Filosofi - Aalborg Universitet.

Casel (Collaborative for Academic, Social, and Emotional Learning) 2003: Safe and sound: An educational leader's guide to evidence-based social and emotional learning (SEL) programs. Chicago: Author.

Dahlstedt, M., A. Fejes \& S. Schönning 2011: "The will to (de)liberate: Shaping governable citizens through cognitive behavioural programmes in school". Journal of Education Policy, vol. 26, no.3.

Elias, M. J., J.E. Zins, R.P. Weissberg, K.S. Frey, M.T. Greenberg, N.M. Haynes, R. Kessler, M.E. Schwab-Stone \& T.P. Shriver 1997: Promoting social and emotional learning: Guidelines for educators. Alexandria, VA: Association for Supervision and Curriculum Development.

Elias, M.J. \& J.E. Zins 2007: "Social and Emotional Learning. Promoting the Development of all Students". Journal of Educational and Psychological Consultation, vol. 17, issue 2-3.

Elias, N. [1939] 1994: The Civilizing Process. Oxford: Blackwell.

Elias, N. 1998: "The civilizing of parents", i J. Goudsblom \& S. Mennell (eds.): The Norbert Elias Reader. Oxford: Blackwell.

Furedi, F. 2004: Therapy Culture. London: Routledge.

Gilliam, L. \& E. Gulløv 2012: Civiliserende institutioner. Om idealer og distinktioner $i$ opdragelse. Aarhus: Aarhus Universitetsforlag.

Gilliam, L. \& E. Gulløv 2014: "Making Children "Social". Civilising institutions in the Danish welfare state". Human Figurations, vol. 3, issue 1.

Gregersen, L. 2002: Bogen om Trin for Trin. En artikelsamling om et undervisningsmateriales teori og praksis. København: Special-Pædagogisk Forlag.

Illouz, E. 2007: Cold Intimacies. The Making of Emotional Capitalism. Cambridge: Polity Press.

Kimber, B. 2004: Att Främja barns och ungdomars utveckling av social och emotionell kompetens. Solna: Ekelunds.

Social Fokus. Børn og unge. Udarbejdet for Socialstyrelsen af Koncernkommunikation, Social- og Integrationsministeriet, juni 2011.

Webster-Stratton, C. 2006: The Incredible Years. A Trouble-Shooting Guide for Parents of Children Aged 2-8 Years. Lancaster: Gazelle Books.

Wouters, C. 1977: "Informalisation and the civilizing process", i P.R. Gleichmann, J. Goudsblom \& H. Korte (eds.): "Human Figurations. Essays for aufsätze für Norbert Elias". Amsterdams Sociologisch Tijdschrift. Amsterdam. 
relstående fami-

maktutövning $i$ institutionen,

ambridge: Pol-

5 \& M. Wiberg iginstitutioner $t 2$, Institut for

2003: Safe and llearning (SEL)

Shaping govool". Journal of

Iaynes, R. Kestional learning: $\imath$ and Curricu-

$g$ the Developltation, vol. 17,

(eds.): The Nor-

stinktioner $i$ op-

titutions in the

jisningsmateria-

nbridge: Polity

emotionell kom-

smmunikation

te for Parents of

Gleichmann, J. Ifsätze für Nor-
Wouters, C. 1986: "Formalization and Informalization: Changing Tension Balances in Civilizing Processes". Theory, Culture \& Society. London, Newbury Park and New Delhi: SAGE, vol. 3, no. 2.

Wouters, C. 2004: "Changing regimes of manners and emotions: from disciplining to informalizing", i S. Loyal \& S. Quilley (eds.): The Sociology of Norbert Elias. Cambridge, UK: Cambridge University Press.

Wouters, C. 2007: Informalization. Manners and Emotions since 1890. London: SAGE Publications.

Eva Gulløv

E-mail: evag@edu.au.dk 